\title{
Role of transient silicon limitation in the development of cyanobacteria blooms in the Guadiana estuary, south-western Iberia
}

\author{
C. Rocha* ${ }^{*}$ H. Galvão, A. Barbosa \\ CIMA-Centre for Marine and Environmental Research, Universidade do Algarve, FCMA—Faculdade de Ciências \\ do Mar e do Ambiente, Campus de Gambelas, 8000-810 Faro, Portugal
}

\begin{abstract}
The Guadiana estuary, located between Portugal and Spain, has the fourth largest drainage basin of Iberian river systems. Up to $75 \%$ of the catchment area has been regulated by dams since the early 1970s. During the 1980s and 1990s, an increasing occurrence of summer cyanobacteria blooms dominated by the potentially toxic Microcystis spp. was reported. In an effort to understand the causes of recurrent noxious blooms in the Guadiana estuary, nutrients (phosphorus, nitrogen [nitrate, nitrite and ammonium], and silicon [silicic acid], chlorophyll a and phytoplankton abundance, specific composition and biomass were evaluated during field surveys, from April 1997 to March 1998. A pattern of successive blooms of different phytoplankton assemblages was observed throughout this period. Diatoms (nano-sized, chain-forming) dominated an early spring bloom (max. $18 \times 10^{3}$ cells $\mathrm{ml}^{-1}$ ) in March and April. Following the decrease in diatom abundance, a chlorophyte bloom (max. $11 \times 10^{3}$ cells ml ${ }^{-1}$ ) and then a cyanobacteria bloom $\left(>6 \times 10^{4}\right.$ cells ml $^{-1}$ ) quickly followed during late spring through to early summer. From July to September, a major cyanobacteria bloom dominated by the potentially toxic Microcystis spp. $\left(>4 \times 10^{5} \mathrm{cells} \mathrm{ml}^{-1}\right)$ developed in the freshwater zone. The results indicate that high winter loads of nitrogen and phosphorus led to the depletion of silicate (down to as low as $0.2 \mu \mathrm{M}$ ) during the early spring diatom bloom, which conditioned the successive phytoplankton assemblages during the remaining productive period. Low monthly discharge rates during spring and summer further provided an environment with low Si:N and N:P relative availability which, coupled with high water-column temperature $\left(>21^{\circ} \mathrm{C}\right)$, seemed to favour the dominance of cyanobacteria over chlorophytes during the summer.
\end{abstract}

KEY WORDS: Southern Portugal · Estuaries · Harmful algal blooms · Eutrophication · Silicon · Nitrate $\cdot$ Cyanobacteria $\cdot$ Dams

\section{INTRODUCTION}

Diffuse pollution of aquatic systems by agricultural land runoff and untreated domestic and industrial effluents has been an undisputed effect of anthropogenic activities related to intensive land use. This pollution has led to increases in nitrogen and phosphorus inputs to estuarine and coastal waters (Officer \& Ryther 1980, Smayda 1990). Conley et al. (1993) distinguished between 2 types of ecosystem-level changes

\footnotetext{
*E-mail: crocha@ualg.pt
}

caused by eutrophication: (1) increased nutrient loading when $\mathrm{N}$ and $\mathrm{P}$ are added to aquatic systems through anthropogenic activities, resulting in increased phytoplankton production, especially of diatoms, and (2) the permanent loss of some fraction of the diatoms produced from the water column and their sequestration in the sediments.

While $\mathrm{N}$ and $\mathrm{P}$ are the 2 most important nutrients governing algal growth (Kilham \& Hecky 1988, Sommer 1989), the relative availability of resources in the aquatic environment may play a major role in structuring phytoplankton communities (Tilman et al. 1982, Sommer 1989, Egge \& Aksnes 1992, Granéli et al. 
1999). Officer \& Ryther (1980) postulated that a change in nutrient composition, with increased availability of $\mathrm{N}$ and $\mathrm{P}$ but not of $\mathrm{Si}$, would be expected to change phytoplankton composition. Because $\mathrm{N}$ and $\mathrm{P}$ recycle faster than $\mathrm{Si}$ in aquatic systems, increased silica retention has been documented in sediments of artificial lakes (Conley et al. 1993). Concomitantly, a reduction in the water-column silica reservoir has been observed, resulting from man-induced modification of biogeochemical cycling: enhanced diatom production results in increased deposition and preservation of diatom silica, leading to a reduction in the watercolumn silicate availability (Schelske \& Stoermer 1971). This second consequence of eutrophication is often linked with water-retention policies included in dam management (Humborg et al. 1997, Milliman 1997), and the process of eutrophication in artificial lakes has been likened to the process arising from reduced silicate loading into the sea (van Bennekom \& Salomons 1981, Humborg et al. 1997).

According to Officer \& Ryther (1980), phytoplankton communities can be separated into 2 basic categories: those dominated by diatoms and those that are not. Growth of diatoms depends on the availability of silicate, while growth of non-diatom phytoplankton usually does not. It is therefore conceivable that a transition between siliceous-based and non-siliceous-based phytoplankton foodwebs will be observed as a result of $\mathrm{N}$ and P enrichment (Turner \& Rabalais 1994). This 'cultural' eutrophication of natural waters has been linked to episodic anoxia events, declining fish and shellfish stocks, and increased frequency of noxious algal blooms - flagellates and cyanobacteria (Turner \& Rabalais 1994, Granéli et al. 1999). For instance, for the central North Sea, Smayda (1990) showed an increase in $\mathrm{N}$ and $\mathrm{P}$, in contrast to unchanging or even decreasing dissolved reactive silicate (DSi) levels over the last few decades associated with increased noxious blooms and a concomitant decrease in the biomass of diatoms. Officer \& Ryther (1980) and Ryther \& Officer (1981) suggested that the diatom foodweb contributes directly to large fish and shellfish populations, while foodwebs based on flagellates or cyanobacteria are undesirable food sources, with these species remaining ungrazed or fuelling foodwebs that are economically undesirable. Moreover, cyanobacteria blooms have been associated with deleterious health effects on local human populations (Chorus \& Bartram 1999).

The present work focuses on the nutritional status of the Guadiana estuary (southern Iberia) and its relationship to the summer dominance of cyanobacteria. The Guadiana has the fourth largest drainage basin of Iberian rivers $\left(67840 \mathrm{~km}^{2}\right)$, but since the $1960 \mathrm{~s}$, dams have been regulating up to $75 \%$ of the freshwater flow (Morales 1997). The recently built Alqueva dam, in- tended to provide irrigation to the largest agricultural area of Portugal, will soon surpass this, regulating $81 \%$ of the total catchment area $\left(55000 \mathrm{~km}^{2}\right)$ from 2002 onwards. Previous studies (1980 to 1985) in the Guadiana estuary revealed the past occurrence of cyanobacteria blooms in association with high nitrogen and phosphorus levels, particularly in years of low freshwater-loading (Cabeçadas \& Brogueira 1981, Oliveira 1985). There is evidence that cyanobacteria blooms have been increasingly frequent since the 1980s (Oliveira 1991, Vasconcelos 1993, INTERREG-II 2000). Monitoring studies of the Guadiana River during the 1990s detected blooms every year from 1996 to 2000, even though a large range of annual freshwater discharge rates was observed during this period (INTERREG-II 2000). Results from these studies are included herein, in an effort to relate transient silicate limitation to the dominance of summer cyanobacteria.

\section{MATERIALS AND METHODS}

Study site. The Guadiana is a mesotidal fluvial-marine system located on the south-western Iberian Peninsula, with the fourth largest drainage basin of Iberian rivers $\left(67840 \mathrm{~km}^{2}\right)$. The total river length is $810 \mathrm{~km}$, of which $550 \mathrm{~km}$ is in Spanish territory and $180 \mathrm{~km}$ in Portuguese territory, with a section of $110 \mathrm{~km}$ serving as the border between south-eastern Portugal and southwestern Spain (Fig. 1). The maximum upstream extent of saltwater penetration coincides approximately with the town of Alcoutim ( $35 \mathrm{~km}$ from the river mouth), while the tidal influence extends an extra $25 \mathrm{~km}$ upstream to the town of Mértola. The drainage basin is located in a temperate climate-zone, characterized by humid, moderate winters and hot, dry summers. The main activities in the catchment area are agriculture and agro-industry. The annual river-flow regime depends on rainfall, with years of very high flow intercalated with long periods of drought. Since the 1960s, the Guadiana's natural flow regime has been strongly constrained by more than 40 dams, which regulate approximately $75 \%$ of the freshwater input into the estuary (Morales 1997), a figure which will soon be greatly surpassed by the recently built Alqueva dam, which will irrigate the largest agricultural area of Portugal, constituting $81 \%$ of the total catchment area $\left(55000 \mathrm{~km}^{2}\right)$. In addition, rainfall and water retention by the dams contributes to the already sharp seasonal and interannual differences in freshwater inputs. This contrasts with the previous dominant 'rainfall regime', which supplied a more even freshwater inflow throughout the year (Fig. 2a). During the last 2 decades, the mean monthly freshwater flow at Pulo do Lobo (Fig. 1) has varied abruptly between wet and dry seasons, with 
peak winter flows ranging from 200 to $600 \mathrm{~m}^{3} \mathrm{~s}^{-1}$ and a minimum of 0.1 to $20 \mathrm{~m}^{3} \mathrm{~s}^{-1}$ in summer, depending on rainfall and dam management.

Nutrient loading (calculated from publicly accessible data of the National Water Institute, INAG, Portugal) derived primarily from drainage of agricultural catchment areas paralleled the freshwater flow regime from 1996 to 1998 (Fig. 2b), with up to $8000 \mathrm{t}$ of dissolved inorganic nitrogen being introduced at Pulo do Lobo in December 1997, and a maximum of $300 \mathrm{t}$ of phosphorus the previous winter (1996). The dissolved N:P ratio of freshwater input during 1997/98 favoured nitrogen during periods of high flow, but was markedly N-deficient during low flow periods in summer and autumn (Fig. 2c). Apart from the input at Pulo do Lobo, the

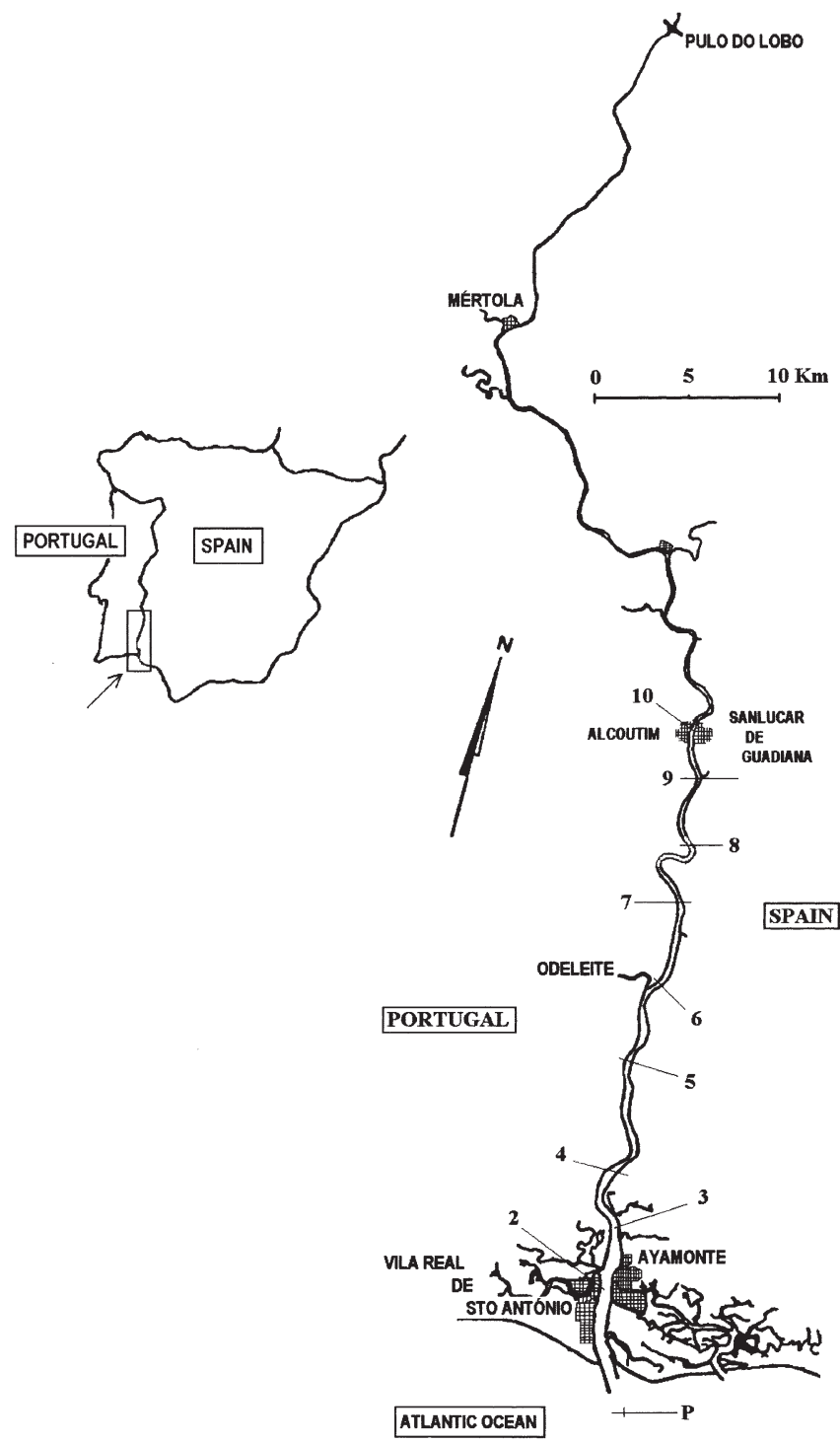

Fig. 1. Location of sampling stations in the Guadiana River and estuary during sampling surveys in 1996 to 1998

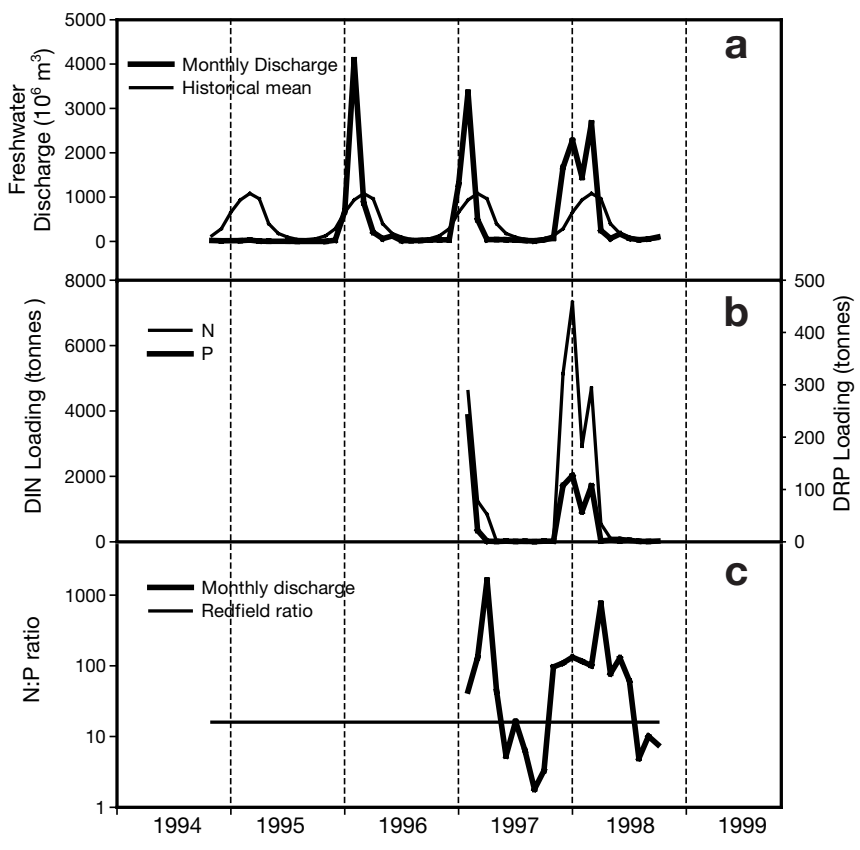

Fig. 2. Data from the hydrological station of Pulo do Lobo (main freshwater input into the Guadiana estuary). (a) Comparison between mean monthly discharges from 1994 to 1998 with historical mean, derived from data taken since beginning of the 20th century. (b) Total dissolved load of DIN (dissolved inorganic nitrogen, $\mathrm{NO}_{3}{ }^{-}+\mathrm{NO}_{2}{ }^{-}+\mathrm{NH}_{4}{ }^{+}$) and DRP (dissolved reactive phosphorus, measured as orthophosphate) introduced with the freshwater input at Pulo do Lobo in the biennium 1997 onto 1998. (c) Aggregate mean monthly loading of nitrogen and phosphorus at Pulo do Lobo in the biennium 1997 to 1998, plotted as the ratio of availability in the water column and compared with the Redfield ratio $(\mathrm{N}: \mathrm{P}=16)$

estuary is subject to other minor mid-estuarine freshwater-loading from tributaries (particularly the Odeleite stream), while other major inputs include sewage, mainly near the mouth, where the population density is highest, with the cities of Ayamonte and Vila Real de Santo António.

Sampling. Sampling stations (Fig. 1) were established along a longitudinal transect covering the salt intrusion zone along the lower Guadiana from the river plume (Stn P) to Alcoutim (Stn 10). Field campaigns started in October and November 1996, as part of a preliminary study, and extended throughout March, April, May, June, July, September and December 1997, ending in March 1998. The primary objective was to characterize the nutritional status of the Guadiana during high-productivity periods. Field surveys were timed to cover the period around high tide $( \pm 2 \mathrm{~h})$. They started at the seaward end (Stn P) 1 to $2 \mathrm{~h}$ before high water. The objective was to sample freshwater at the time of high tide. This strategy accomplished the double objective of sampling when tidal velocities 
were lower, thus reducing the possibility of sample streaming.

All surveys were undertaken from small boats; conductivity and temperature measurements were made at every station with Field CT meters (YSI-30 and WTW LF196) calibrated with seawater standard solutions. At every station, a van Dorn 81 sampling bottle was used to sample water at $1 \mathrm{~m}$ depth for subsequent determination of dissolved oxygen, ammonium, nitrate (occasionally nitrite), phosphorus, silicate and suspended solids. Dissolved oxygen samples were collected, preserved and analysed by the Winkler method (Parsons et al. 1984). On board ship, samples for nutrient concentration were pre-filtered through cellulose acetate filters (porosity $=0.45 \mu \mathrm{m}$ ). Filtered samples were treated with mercuric chloride to a final concentration of $20 \mathrm{mg} \mathrm{l}^{-1}$ (Oremland \& Capone 1988, Kirkwood 1992) and chilled $\left(4^{\circ} \mathrm{C}\right)$ until analysis by a SKALAR 4-channel seawater segmented flow analyser with routine spectrophotometric methods, modified for variable salinity.

Filtration for chlorophyll determination was also performed on board: $200 \mathrm{ml}$ of water was filtered under low pressure ( $<100 \mathrm{~mm} \mathrm{Hg}$ ) in the dark (to avoid photodegradation of pigments) through Whatman GF/F filters. The filters were then folded, frozen and subsequently extracted with aqueous ethanol (96\%) for $24 \mathrm{~h}$. Pigment concentration was determined by spectrofluorometry at $664 \mathrm{~nm}$ with excitation at $425 \mathrm{~nm}$ (Baltic Sea Environmental Proceedings 1988).

Water samples for the enumeration of picophytoplankton, nanophytoplankton and microflagellates other than dinoflagellates were preserved with glutaraldeyde $(2 \% \mathrm{v} / \mathrm{v}$ final concentration), stained with proflavine $(1 \% \mathrm{v} / \mathrm{v})$, and gently filtered $(<50 \mathrm{~mm} \mathrm{Hg})$ onto $0.4 \mu \mathrm{m}$ black Nuclepore filters. Filters were mounted in glass slides with immersion oil (Cargille Type A). All preparations were made within $24 \mathrm{~h}$ of sampling and stored at $-10^{\circ} \mathrm{C}$ to mimimize the loss of autofluorescence. A minimum of 50 random fields or 200 cells was counted at $600 \times$ to $1250 \times$ magnification with a Leitz Laborlux epifluorescence microscope equipped with blue light illumination (Haas 1982). Samples for the enumeration of micro $(>20 \mu \mathrm{m})$ diatoms and dinoflagellates were preserved with acid Lugol, sedimented in sedimentation chambers for 24 to $48 \mathrm{~h}$, and observed at $200 \times$ to $400 \times$ magnification with a Wild inverted microscope (Utermöhl 1958). More than 100 cells of the most common taxa were counted (Lund et al. 1958). The dimensions of a minimum of 50 randomly selected individuals of each species/group were measured using a calibrated ocular micrometer, and biovolume estimates were calculated from linear dimensions using appropriate geometric configurations (Edler 1979). The cell volumes of diatoms and dinoflagellates were subsequently converted to carbon biomass using the allometric relations of Strathmann (1967). The biomass of freshwater chlorophytes and cyanobacteria was calculated according to Rocha \& Duncan (1985), and the biomass of the remaining phytoplanktonic cells according to Verity et al. (1992).

\section{RESULTS}

\section{Temperature and salinity}

The freshwater temperature data showed a predictable seasonal pattern, with lowest temperatures $\left(11\right.$ to $\left.14^{\circ} \mathrm{C}\right)$ in December and highest temperatures in summer $\left(25\right.$ to $\left.28^{\circ} \mathrm{C}\right)$, at which time coastal waters where colder (vice-versa in winter). The vertical temperature structure was always homogeneous, with little or no vertical gradient observed in the dilution zone. The extent of saltwater penetration into the estuary (Fig. 3) was relatively stable during the springautumn period, corresponding to low freshwater discharge (March to October: see Fig. 2a). However, in winter during high discharge periods, virtually no salinity structure was observed within the estuary, with values as low as 14 PSU measured in the estuarine plume zone in December. Therefore, the Guadiana is a freshwater-dominated estuary only in periods of very high flow in winter, while for the spring-autumn period the salinity distribution is controlled by the tides, with strong vertical mixing during spring tides (Fig. 3b) and a salt-wedge forming only during neap tides (Fig. 3a). The maximum extent of the dilution zone was always less than $40 \mathrm{~km}$, never extending further than the town of Alcoutim.

\section{Phytoplankton}

Seasonal trends in chlorophyll a concentrations in the estuary followed a clear pattern, with maxima during spring and late summer and minima in winter and late spring. A clear freshwater chlorophyll maximum was observed throughout the year (Table 1), with recorded levels surpassing $40 \mathrm{mg} \mathrm{m}^{-3}$ during early spring; minimum concentrations were observed at the saline water influence zone in winter and late spring.

Longitudinal distributions of abundance, plotted to highlight the succession of 3 major groups (diatoms, chlorophytes and cyanobacteria), combined with seasonal variability, revealed a pattern of successive blooms of different phytoplankton assemblages was evidenced throughout 1997 (Fig. 4). Diatoms dominated an early spring bloom in March and April. Following the decrease in diatom abundance, a chlorophyte and then a 

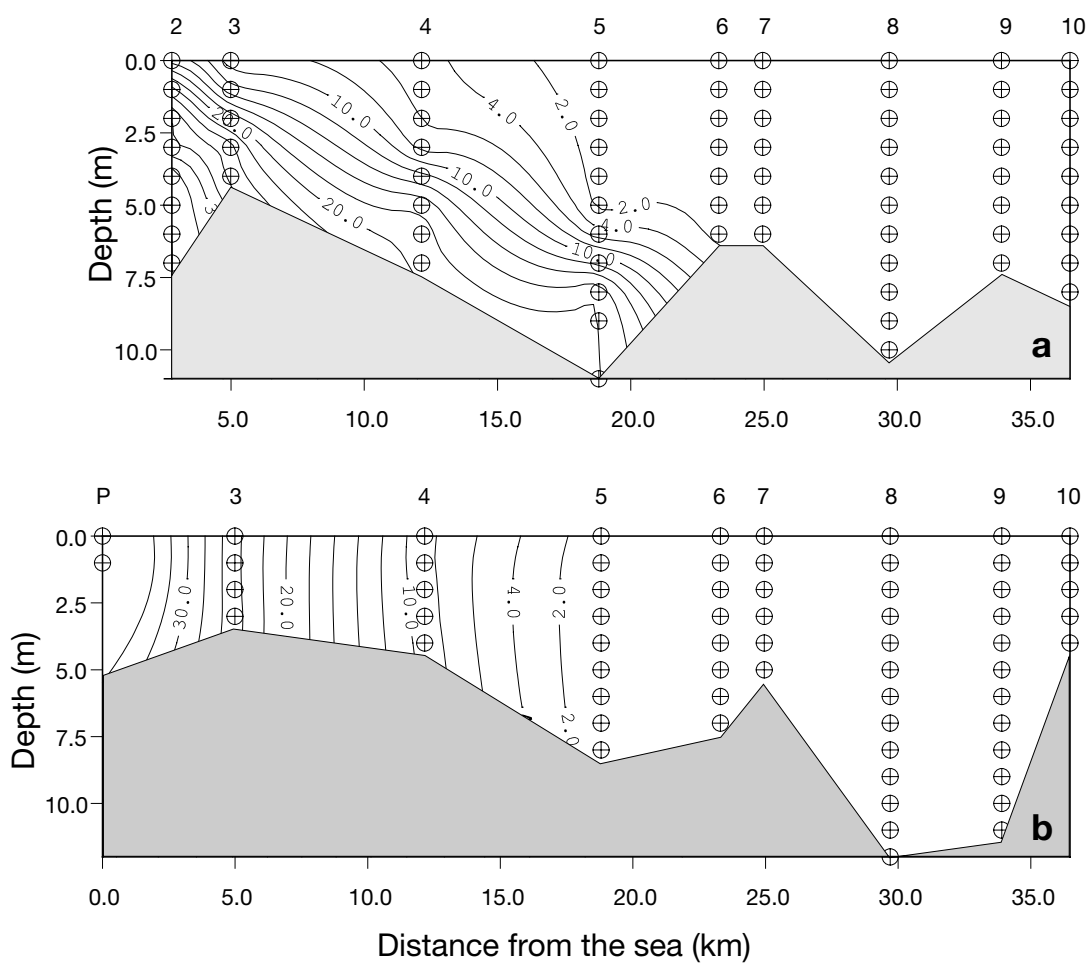

Fig. 3. Interpolation plot showing salinity structure along the surveyed section of the Guadiana estuary, during neap tide (a) and spring tide (b) in March 1997. $(\oplus)$ Sampling depths; numbers on top abscissas: sampling stations

Table 1. Nutrient concentrations at selected sampling stations during the survey period, representing a geographical gradient from the freshwater end-member (Stn 10), through the mid-salinity range (Stn 5) to the saline end-member of the estuary (Stn 2). Samples collected at $1 \mathrm{~m}$ depth. Sal: salinity; DSi: dissolved reactive silicate; DRP: dissolved reactive phosphorus; DIN: dissolved inorganic nitrogen; nd: not determined

\begin{tabular}{|c|c|c|c|c|c|c|c|}
\hline & $\begin{array}{c}\text { Apr } \\
97\end{array}$ & $\begin{array}{c}\text { May } \\
97\end{array}$ & $\begin{array}{c}\text { Jun } \\
97\end{array}$ & $\begin{array}{l}\text { Jul } \\
97\end{array}$ & $\begin{array}{c}\text { Sep } \\
97\end{array}$ & $\begin{array}{c}\text { Dec } \\
97\end{array}$ & $\begin{array}{c}\text { Mar } \\
98\end{array}$ \\
\hline \multicolumn{8}{|c|}{ High-estuary (Stn 10) } \\
\hline Sal (PSU) & 0.004 & 0.005 & 0.004 & 0.005 & 0.52 & nd & 0.10 \\
\hline $\mathrm{DSi} \quad(\mu \mathrm{M})$ & 3.85 & 3.46 & 0.21 & 4.81 & 28.4 & 176 & 1.00 \\
\hline $\mathrm{DRP} \quad(\mu \mathrm{M})$ & 1.21 & 8.72 & 1.81 & 2.78 & 0.92 & 0.37 & 0.02 \\
\hline DIN $(\mu \mathrm{M})$ & 61.2 & 26.4 & 4.09 & 2.37 & 11.7 & 67.3 & 86.4 \\
\hline Chla $\left(\mu g \mathrm{l}^{-1}\right)$ & 14.9 & 4.08 & 7.63 & 22.5 & 30.5 & 2.10 & 35.6 \\
\hline \multicolumn{8}{|c|}{ Mid-estuary (Stn 5) } \\
\hline Sal (PSU) & 3.16 & 1.74 & 0.94 & 1.17 & 2.01 & nd & 0.10 \\
\hline $\mathrm{DSi} \quad(\mu \mathrm{M})$ & 9.04 & 1.07 & 0.21 & 1.86 & 9.52 & 215 & 6.40 \\
\hline $\mathrm{DRP} \quad(\mu \mathrm{M})$ & 1.27 & 5.48 & 0.50 & 0.31 & 1.78 & 2.80 & 0.02 \\
\hline DIN $(\mu \mathrm{M})$ & 54.3 & 41.8 & 2.79 & 0.73 & 0.56 & 91.5 & 84.2 \\
\hline Chla $\left(\mu g \mathrm{l}^{-1}\right)$ & 5.78 & 1.11 & 1.34 & 15.6 & 19.4 & 1.88 & 30.6 \\
\hline \multicolumn{8}{|c|}{ Low-estuary (Stn 2) } \\
\hline Sal (PSU) & 16.35 & 15.9 & 10.73 & 12.44 & 22.73 & 6.50 & 12.30 \\
\hline $\mathrm{DSi} \quad(\mu \mathrm{M})$ & 6.88 & 0.50 & 0.45 & 1.36 & 5.77 & 124 & 1.40 \\
\hline $\mathrm{DRP} \quad(\mu \mathrm{M})$ & 0.53 & 22.7 & 0.13 & 0.13 & 1.00 & 1.94 & 0.10 \\
\hline DIN $(\mu \mathrm{M})$ & 35.0 & 26.4 & 1.20 & 2.53 & 5.92 & 62.4 & 110 \\
\hline Chla $\left(\mu g \mathrm{l}^{-1}\right)$ & 5.96 & 0.93 & 2.15 & 9.33 & 8.21 & 1.92 & 15.7 \\
\hline
\end{tabular}

cyanobacteria bloom quickly followed during late spring through to early summer. From July to September, a major cyanobacteria bloom developed in the freshwater zone. By late summer, a secondary diatom bloom had also developed in the higher reaches of the estuary. In terms of abundance, chain-forming nanodiatoms dominated the early spring diatom bloom in the low-salinity regions (max. $18 \times 10^{3}$ cells $\mathrm{ml}^{-1}$ ), while the subsequent chlorophyte bloom (max. $11 \times 10^{3}$ cells $\mathrm{ml}^{-1}$ ) comprised mainly the freshwater species Monoraphidium contortum, Micractinium pusilum, Scenedesmus spp. and Pediastrum spp. The first cyanobacteria bloom $(>6 \times$ $10^{4}$ cells $\mathrm{ml}^{-1}$ ) in mid-June was dominated by the filamentous Oscillatoria spp. and unicellular colony-forming Microcystis spp. However, the potentially toxic Microcystis spp. dominated the ensuing summer and fall cyanobacteria bloom, with a total abundance higher than $4 \times 10^{5}$ cells ml $\mathrm{m}^{-1}$ at Alcoutim (Stn 10). The secondary diatom and chlorophyte blooms of late summer (September) were small compared to the cyanobacteria proliferation, with abundances 2 and 3 orders of magnitude lower than that of cyanobacteria, respectively.

\section{Nutrient status}

Table 1 shows nutrient concentrations at selected sampling stations during the survey period, representing a geographical gradient from the freshwater endmember (Stn 10) through the mid-salinity range (Stn 5) to the saline end-member of the estuary (Stn 2). Dissolved reactive silicate (DSi, measured as silicate, $\mathrm{H}_{4} \mathrm{SiO}_{4}$ ) peaked at all stations during winter flushing of the estuary by freshwater discharge, with levels occasionally surpassing $200 \mu \mathrm{mol} \mathrm{dm}{ }^{-3}$. However, during the productive period (spring-fall) DSi concentrations were usually less than $5 \mu \mathrm{mol}$ $\mathrm{dm}^{-3}$, except in September, when dissolved levels started to recover. Concentrations below $1 \mu \mathrm{mol} \mathrm{dm}{ }^{-3}$ were measured during early summer in June, occurring in the low-salinity regions of the estuary (Stns 10 through 6). Although a pulse input at Stn 6 (Odeleite stream) was 


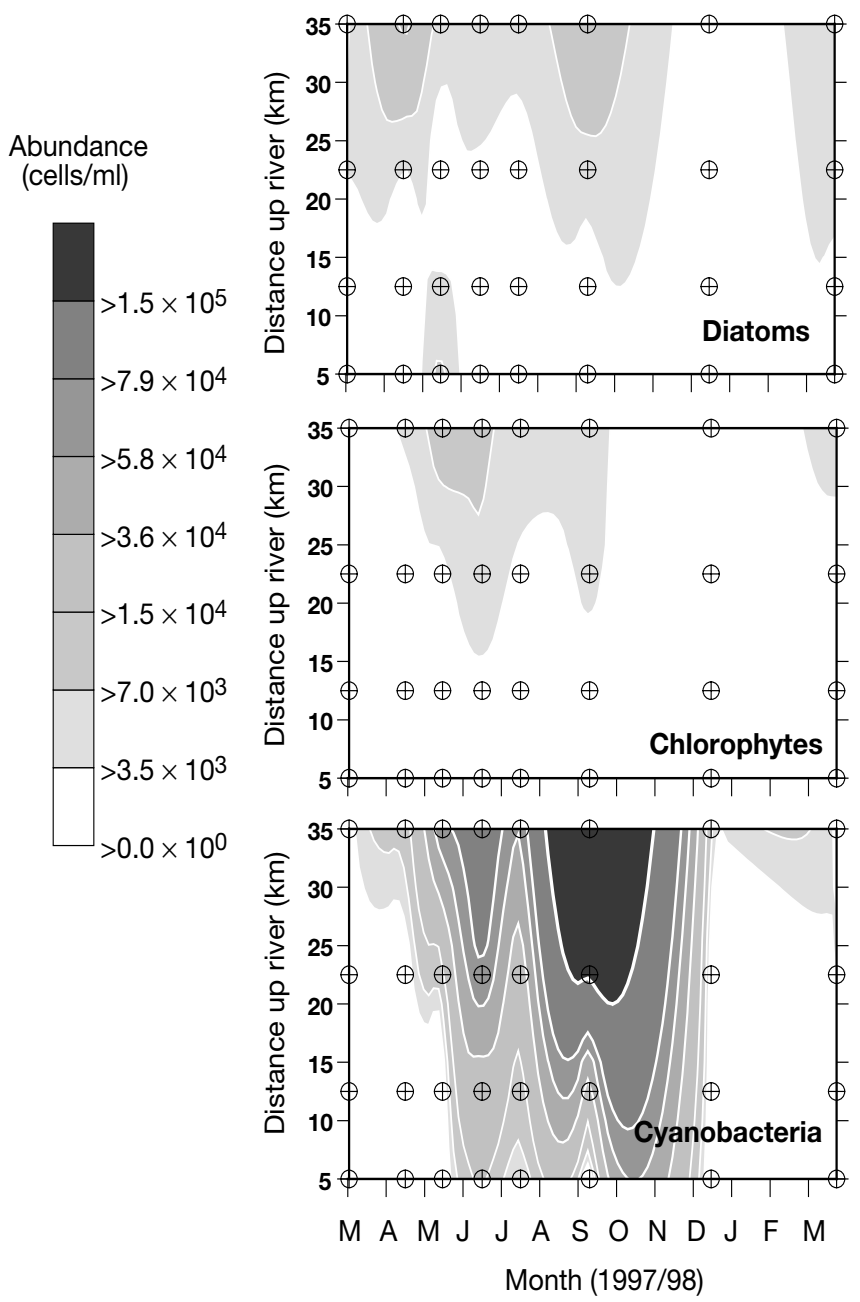

Fig. 4. Interpolation plots aggregating longitudinal and seasonal distribution of phytoplankton abundances of specific groups (diatoms, chlorophytes and cyanobacteria) at selected sampling stations, representing a salinity gradient within the estuary

evidenced by the nutrient-salinity relationships for April (Fig. 5), which affect the dilution gradient downstream, DSi concentrations were extremely low in the dilution zone throughout the spring-fall period, when the most important algal blooms developed (Fig. 4). From May to July, the measured gradient (compared to theoretical dilution lines: Liss 1976) evidenced heavy water-column removal of DSi starting in the low-salinity zone. DSi in the water column evidenced mild recovery in September, probably due to the remineralisation of sedimented diatom frustules from the early spring bloom. The removal of DSi from the water column revealed by the nutrient-salinity plots (Fig. 5), in parallel with the observed development of a secondary diatom bloom in late summer (Fig. 4), indicated that diatoms grew in response to this new input.
Concentrations of dissolved reactive phosphate (DRP, measured as orthophosphate) were quite high ( $>5 \mu \mathrm{mol} \mathrm{dm}{ }^{-3}$ ) during late spring in the whole estuary, while during the rest of the year they remained below $2 \mu \mathrm{mol} \mathrm{dm}{ }^{-3}$. Concentrations ranged from minima close

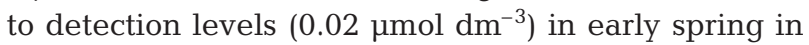
1998 in the low-salinity areas to maxima of over $8 \mu \mathrm{mol}$ $\mathrm{dm}^{-3}$ in the freshwater-influenced zone in May 1997. The increase in phosphorus availability in the water column in May (Fig. 5) was an effect of the relatively high phosphorus loading at Pulo do Lobo (Fig. 2c) during this month. Blooms of both green and blue-green algae during June (Fig. 4) seemed to benefit from this additional $\mathrm{P}$ availability, as evidenced by its removal from the water column (evident from the nutrient salinity plots in Fig. 5). Furthermore, the significant positive correlations between phosphorus availability and biomass of both chlorophytes and cyanobacteria (Table 2), suggest that growth of these 2 groups was phosphoruslimited before May/June. Evidence of heavy imbalance in favour of $\mathrm{N}$ enrichment (highest $\mathrm{N}$ :P ratio of the year) at the loading point (Fig. 2c) during winter 1997 corroborates this interpretation of the data.

Dissolved inorganic nitrogen (DIN, representing the summation of $\mathrm{NO}_{3}{ }^{-}, \mathrm{NO}_{2}^{-}$and $\mathrm{NH}_{4}{ }^{+}$) followed the variation in nitrogen freshwater-loading (Fig. 2b,c), as evidenced by a strong positive correlation between nitrate and discharge at Alcoutim (Stn 10), with minimum concentrations in summer, during periods of low freshwater flow, and maximum concentrations in winter, when discharge was highest (Fig. 2a,c). Concentra-

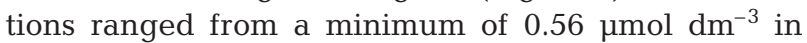
mid-estuarine regions and maxima of $110 \mu \mathrm{mol} \mathrm{dm}{ }^{-3}$ near the estuarine mouth. The high DIN concentrations near the estuarine mouth (Fig. 5) were heavily influenced by high ammonium concentrations, probably linked to the anthropogenic effect of the markedly seasonal sewage-effluent plumes from the towns of Vila Real and Ayamonte (Fig. 1).

Table 2. Spearman's rank-correlation coefficient of biological and chemical variables at Stn 10 (Alcoutim) during the survey period. ${ }^{* * *} p<0.001,{ }^{*} p<0.05$. DRP: dissolved reactive phosphorus; chloro: chlorophytes; cyano: cyanobacteria

\begin{tabular}{|lcccc|}
\hline & DRP & Nitrate & $\begin{array}{c}\text { Biomass } \\
\text { chloro }\end{array}$ & $\begin{array}{c}\text { Biomass } \\
\text { cyano }\end{array}$ \\
\hline Discharge & $-0.620^{*}$ & $0.874^{* * *}$ & $-0.700^{*}$ & -0.550 \\
& $(\mathrm{n}=10)$ & $(\mathrm{n}=8)$ & $(\mathrm{n}=9)$ & $(\mathrm{n}=9)$ \\
DRP & & -0.452 & $0.750^{*}$ & $0.683^{*}$ \\
& $(\mathrm{n}=8)$ & $(\mathrm{n}=9)$ & $(\mathrm{n}=9)$ \\
Nitrate & & $-0.786^{*}$ & $\begin{array}{c}-0.571 \\
(\mathrm{n}=7)\end{array}$ \\
Biomass chloro & & & $0.900^{* * *}$ \\
& & & & $(\mathrm{n}=9)$ \\
\hline
\end{tabular}



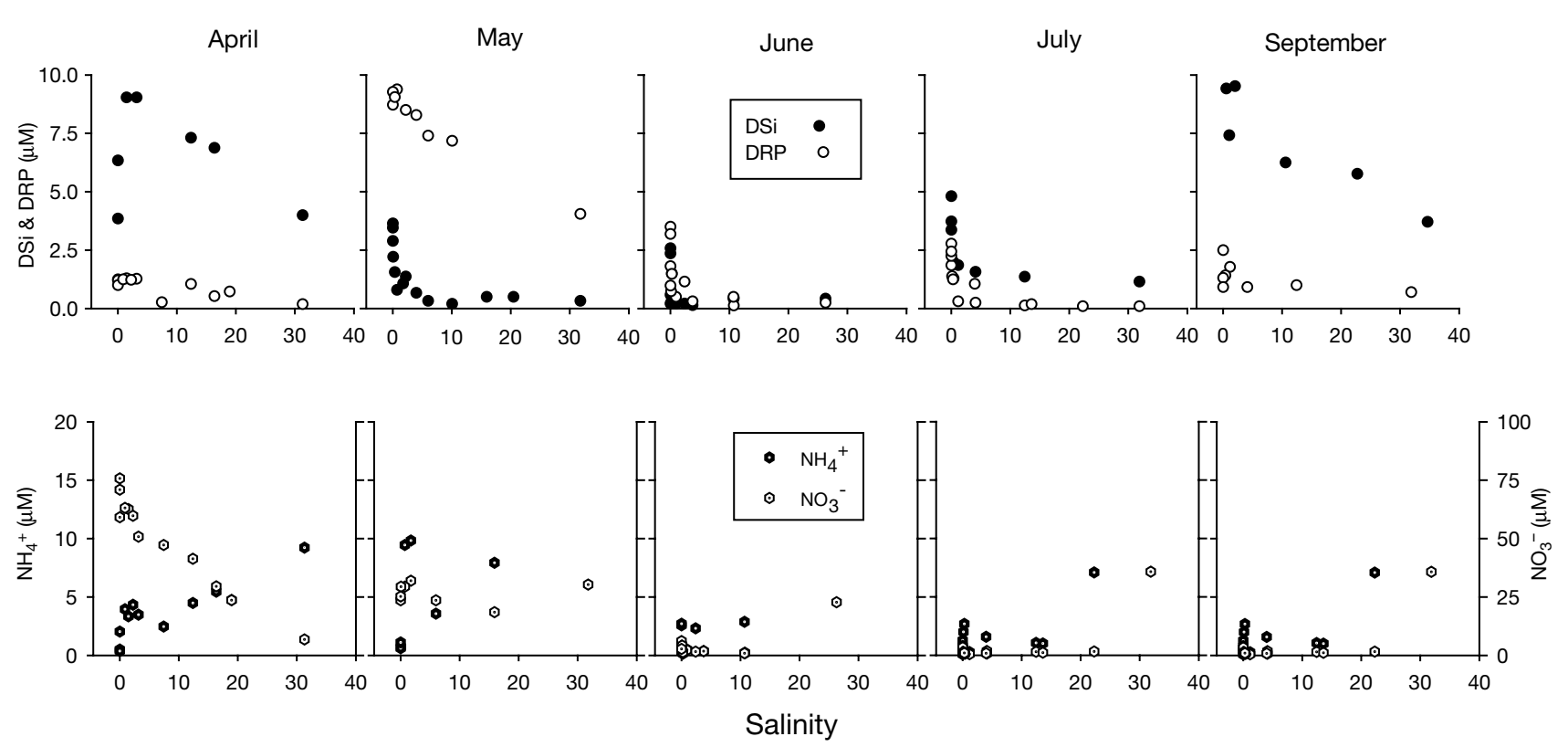

Fig. 5. Nutrient-salinity relationships during the productive season in the Guadiana estuary in 1997

\section{DISCUSSION}

\section{Spring transition: diatom to non-diatom assemblages}

During 1997, the phytoplankton succession in the Guadiana estuary showed a clear transition from a diatom-dominated early spring bloom to absolute dominance of cyanobacteria in summer. Although there was a secondary diatom bloom by September (Fig. 4), as a result of a fresh input of dissolved silicate (Fig. 5), cell densities were quite low compared to those of the cyanobacteria. The enrichment of catchment areas in $\mathrm{N}$ and $\mathrm{P}$ (but not Si) caused by human activities (cultural eutrophication) has been hypothesised as leading to a shift from diatom-based to non-diatom-based phytoplankton foodwebs (Officer \& Ryther 1980, Ryther \& Officer 1981). This transition has been frequently attributed to enhanced growth of diatoms in response to increased $\mathrm{N}$ and $\mathrm{P}$ availability and a resultant exhaustion of DSi supplies (Schelske \& Stoermer 1971, Smayda 1990, Egge \& Asknes 1992).

Very high freshwater inputs of $\mathrm{N}$ and $\mathrm{P}$ (Fig. 2b,c), and even DSi (Table 1) were observed during winter, with a subsequent high freshwater discharge, depletion of dissolved silicate from May to July, and the collapse of the spring diatom bloom, suggesting that specific nutrient availability during the productive period exerted a tight control over the phytoplankton succession in the estuary. Since transition of ecosystems from siliceous-based to non-siliceous-based phytoplanktonic communities has been associated with a deleterious effect on water quality (Smayda 1990, Turner \& Raba- lais 1994), the potential resource limitation effect on phytoplankton growth will be discussed in regard to the composition of diatomaceous organic matter. The accepted standard molar ratios between DIN, DSi and DRP for marine diatom biomass growth is $\mathrm{Si}: \mathrm{N}: \mathrm{P}=$ 16:16:1 (Redfield et al. 1963, Brzezinski 1985). These ratios are within the minimum-scale range for freshwater phytoplankton, since it has been shown that dissolved silicate demand by freshwater diatoms is higher than that by marine species (Paasche 1980). In Fig. 6, molar quotients between the in situ concentrations of potentially limiting nutrients are delimited by the $\mathrm{Si}: \mathrm{N}=1, \mathrm{~N}: \mathrm{P}=16$ and Si:P = 16 lines. These define 6 different areas within Fig. 6, with each characterized by the potentially limiting nutrients in order of priority (see Fig. 6d). It should be emphasized that no suggestion is being made that nutrient ratios per se were the defining environmental variable conditioning bloom succession (Bulgakov \& Levitch 1999, Smith \& Bennett 1999). These ratios are merely used to define resource availability (Sommer 1993, del Amo et al. 1997) as the consequence of loading and biotic activity (Reynolds 1999, Sommer 1999).

The relative proportion of available nutrients evidences a clear cycle during the productive period in the low-salinity zone (Fig. 6a). As a consequence of the diatom bloom in March and April (Fig. 4), DSi depletion occurred in the whole estuary in May (Fig. 5), with available concentrations falling below reported half-saturation constants for DSi incorporation by diatoms (marine and coastal diatoms: $K_{\mathrm{m}}=1$ to $5 \mu \mathrm{M}$ [Fisher et al. 1988] and 0.03 to $3.37 \mu \mathrm{M}$ [Dortch \& Whitledge 1992]; fresh- 


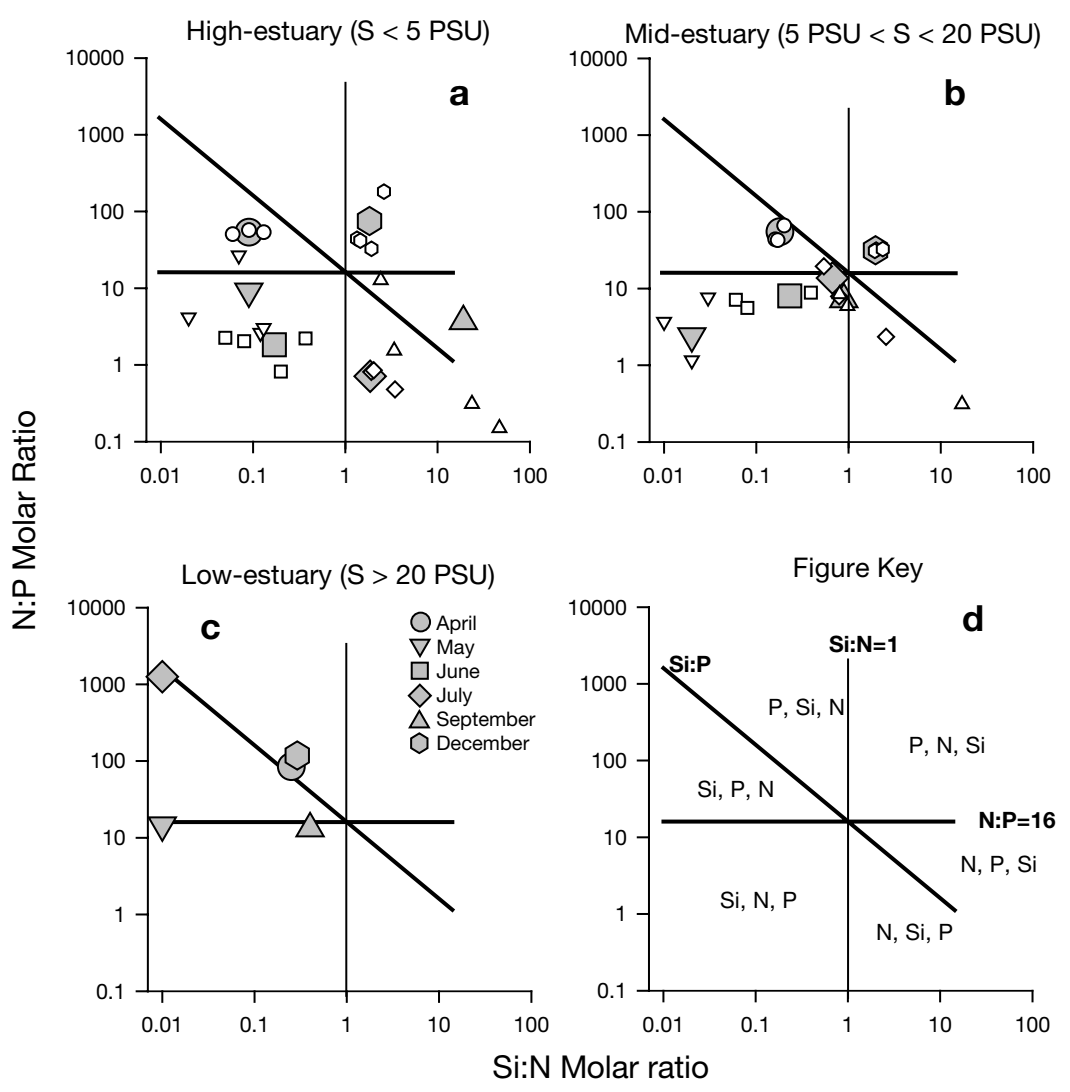

Fig. 6. Si:N:P molar ratios in the water column of the Guadiana estuary in 1997. Grey symbols: average values from representative stations during a specific month; smaller, white symbols: individual measurements at a specific station. (a) Sampling stations located within low salinity zone (Stns 6, 7, 8 and 10); (b) sampling stations located within the average salinity zone (Stns 5, 4 and 3 and occasionally Stn 2); (c) estuarine plume zone (Stn P). Horizontal and vertical lines: Redfield et al. (1963) ratio (N:P) and Brzezinski (1985) ratio (N:Si), respectively. Diagonal line: aggregate ratio (Si:N:P = 16:16:1). (d) Figure key. For further details and explanation, see 'Discussion'

tributed to the observed succession in species domination, when diatoms exhausted the resource, influencing the subsequent species composition in the estuary. This observation is similar to those in Lake Michigan by Schelske \& Stoermer (1971), the North Sea by Smayda (1990), and in the Mississippi River delta by Turner \& Rabalais (1994).

\section{Summer dominance: greens or blue-greens?}

During the spring-summer transition, after the collapse of the early spring diatom population, a chlorophyte bloom developed (Fig. 4). Higher phosphorus concentrations in May (Fig. 5), probably because of delayed availability (Fig. 2b,c), could explain (chlorophyte biomass correlates positively with phosphorus availability: Table 2) the enhanced growth of this phytoplankton assemblage (Fig. 4). The question that arises for the Guadiana estuary is therefore, once low DSi restricts diatoms, why do the cyanobacteria dominate summer populations, and not green algae?

The sequence of summer dominance is generally accepted to be the result of grazing selectivity and multispecies competition for available nutrients (Sommer 1989), occasionally modulated by temperature (Tilman et al. 1981, Tilman \& Kiesling 1984, Paerl 1988, Grover et al. 1999). During May and June, the relative nutrient availability in the Guadiana estuary falls

water diatoms: $K_{\mathrm{m}}=0.12$ to $1.5 \mu \mathrm{M}$ for centric diatoms and 1.5 to $19.5 \mu \mathrm{M}$ for other species; Tilman et al. 1982). This is clear from Fig. 6a, where resource ratios fall into the region in which DSi limitation is most likely to occur.

In short, water-column consumption by phytoplankton in the low-salinity zone conditioned nutrient concentrations downriver from Alcoutim (Fig. 5). DSi was the nutrient most likely to be limiting after the March/ April bloom in brackish (Fig. 6b) and saline areas (Fig. 6c) of the estuary, with very low Si:N and Si:P availability ratios $(0.01<\mathrm{Si}: \mathrm{N}<0.13 ; 0.001<\mathrm{Si}: \mathrm{P}<0.04)$. The results indicate, therefore, that phytoplankton consumption, as well as low nutrient-loading, conditioned the succession of phytoplankton species in the Guadiana estuary on both a temporal and a spatial scale, as reported for other similar systems (Fisher et al. 1988, 1992, Cloern 1991, 1996). Clearly, low relative DSi availability in early spring in the Guadiana con- within the $\mathrm{N}$ limiting area (Fig. 6), with low N:P ratios (0.82 to 7.6). Freshwater blue-green and green algae have relatively low $\mathrm{P}$ requirements $\left(K_{\mathrm{m}}=0.03\right.$ to 1.89 $\mu \mathrm{M}$ : Tilman et al. 1982), and phosphorus is available above these concentrations during the spring-summer transition (Fig. 5, Table 1). However, literature evidence suggests that green algae are the poorest $\mathrm{N}$ competitors, but dominate over cyanobacteria in $\mathrm{P}$ competition (Sommer 1989). As a consequence, they tend have a competitive advantage in ecosystems with low $\mathrm{Si}: \mathrm{P}$, but high N:P availability ratios. Even at nonsteady state (Sommer 1985), under pulsed conditions, green algae are specially adapted to scavenge available phosphorus both for rapid growth (Scenedesmus spp. and Chlorella spp. are $r$-strategists) and P storage (Pediastrum spp. is a $K$-strategist). Conversely, cyanobacteria have other advantages, especially in conditions favouring $\mathrm{P}$ over $\mathrm{N}$ availability (Fig. 6). During 
the spring-summer transition, and up until early fall, nitrogen was increasingly scarce in the higher reaches of the Guadiana estuary (Figs. 2c, 5 \& 6), water temperatures were quite high $\left(>21^{\circ} \mathrm{C}\right.$, occasionally $>25^{\circ} \mathrm{C}$ ), and light availability in the water column quite low (extinction coefficient $=2.5$ to $3 \mathrm{~m}^{-1}$, based on Secchi depth).

Cyanobacteria have been described as the favoured taxa under high $\left(>21^{\circ} \mathrm{C}\right)$ temperatures, both in laboratory experiments (Tilman \& Kiesling 1984) and in field conditions (Paerl 1988). In the resource environment described above for the Guadiana estuary, although the spring-summer transition can be dominated by chlorophytes, eventually cyanobacteria predominate (see Grover et al. 1999 and references therein). In fact, apart from being favoured by low $\mathrm{N}: \mathrm{P}$ ratios and high temperatures, cyanobacteria possess the advantage over chlorophytes of being less affected by loss factors due to grazing (Sterner 1989) and sedimentation (Sommer 1989). Cyanobacteria, especially colony-forming species (Microcystis spp.), are nearly impervious to sedimentation losses, and are excellent light competitors in turbid water columns because of their capacity to regulate buoyancy (Sommer 1989). In addition, they constitute a poor food source for zooplankton in regard to nutritious value and toxin defensiveness (DeMott \& Muller-Navarra 1997, DeMott 1998), and are able to form large, bulky colonies (Fulton \& Paerl 1987). Consequently, reduced grazing and sedimentation losses, as well as low light availability, will benefit cyanobacteria over other taxa in a multispecies assemblage. In addition, Microcystis spp. appears to be a 'storage specialist' of nitrogen ( $K$-strategist), which would confer higher long-term survivability over chlorophytes under conditions of low N:P resource availability (Sakshaug \& Olsen 1986, Kilham \& Hecky 1988). In this way, environmental conditions in the Guadiana estuary in the spring-fall of 1997 favoured cyanobacteria predominance in the summer, especially in the upper reaches of the estuary.

\section{Concluding remarks}

Earlier studies (1980 to 1985) in the Guadiana estuary revealed the occurrence of cyanobacteria blooms in association with high nitrogen and phosphorus levels, particularly in years of low freshwater-loading (Cabeçadas \& Brogueira 1981, Oliveira 1985). Since the 1980s, cyanobacteria blooms have been increasingly frequent (Oliveira 1991, Vasconcelos 1993, INTERREG-II 2000), despite a large range of annual freshwater-discharge rates during this period (INTERREG-II 2000).
Apart from the deleterious effect of the observed transition to a non-siliceous, phytoplankton-dominated ecosystem (Smayda 1990), with its long-term effects on water quality and on the economical value of this resource, noxious summer blooms present a more direct and serious health hazard (Chorus \& Bartram 1999) to local human populations. This study confirms the conclusions of previous work (Cabeçadas \& Brogueira 1981, Oliveira 1985, 1991) indicating that the majority of cyanobacteria comprising the summer blooms in the Guadiana estuary are potential toxin producers (Microcystis spp. and Anabaena spp.). Their presence has been related to fish mortality (Oliveira 1991), and to outbreaks of gastroenteritis in the local population (Vasconcelos 1993). The association between low relative DSi-loading and summer cyanobacteria blooms described in this paper cannot be dissociated from 2 possible causal agents: cultural eutrophication, represented by the enrichment in DIN and DRP through agricultural activities in the catchment areas (Officer \& Ryther 1980, Smayda 1990), and water retention by the cascading effect of more than 40 dams in the Guadiana drainage basin, which regulate approximately $75 \%$ of the water flow (Morales 1997). In fact, the trapping of water and sediments by dams, among other effects (Milliman 1997), has been shown to reduce nutrient-loadings through the removal of reservoir sediments (van Bennekom \& Salomons 1981), specifically affecting the dissolved-silicate-loading (due to enhanced retention of Si) into receiving estuaries and coastal seas (Humborg et al. 1997), and thereby disturbing the ecosystem structure by conditioning diatom growth (Officer \& Ryther 1980, Smayda 1990, Turner \& Rabalais 1994, Humborg et al. 1997). In view of the ongoing construction of the Alqueva dam complex, which will further increase the regulation of water flow in the Guadiana drainage basin to a disturbing $81 \%$, the results presented here are particularly important, and should be carefully considered in overall environmental and socio-economical impact estimates.

Acknowledgements. Research for this paper was co-financed by INTERREG-II (Study of Cyanobacteria Blooms in Response to Discharge Variability in the Guadiana, contract number 16/REGII/6/96; General Characterization of the Guadiana Estuary as Basis for the Evaluation of Environmental Change, contract number 15/REGII/6/96). Technical support during the fieldwork by Rita Baptista, Sandra Caetano, Raquel Coimbra, Claudia Miguel, Pedro Mendes, Sandra Mesquita and Pedro Morais is gratefully acknowledged. Special thanks are due to Sandra Caetano for carrying out the epifluorescence work and to Claudia Miguel for the inverse microscopy. The Portuguese National Foundation for Science and Technology (FCT) provided funding for C.R. through contract PRAXIS XXI/BPD/18849/98. Thanks are due to 3 anonymous reviewers, whose comments helped to improve the original manuscript. 


\section{LITERATURE CITED}

Baltic Sea Environmental Proceedings (1988) Guidelines for the Baltic Monitoring program for the Third Stage. Biological Determinands No. 27. D: Baltic Marine Environment Protection Commission, Helsinki

Brzezinski MA (1985) The Si:C:N ratio of marine diatoms: interspecific variability and the effect of some environmental variables. J Phycol 21:347-357

Bulgakov NG, Levitch AP (1999) The nitrogen:phosphorus ratio as a factor regulating phytoplankton community structure. Arch Hydrobiol 146:3-22

Cabeçadas G, Brogueira MJ (1981) Notas sobre a qualidade da água do Rio Guadiana. Internal report No. 42, IPIMAR, National Institute for Fisheries and Marine Research, Lisbon (in Portuguese)

Chorus I, Bartram J (1999) Toxic cyanobacteria in water-a guide to their public health consequences, monitoring and management. Published on behalf of the World Health Organization, E \& FN Spon, London

Cloern JE (1991) Annual variations in river flow and primary production in the South San Francisco Bay estuary. In: Elliot M, Ducrotoy JP (eds) Estuaries and coasts: spatial and temporal intercomparisions. Olsen \& Olsen, Fredensborg, p 91-96

Cloern JE (1996) Phytoplankton bloom dynamics in coastal ecosystems: a review of some general lessons from sustained investigation of San Francisco Bay, California. Rev Geophys 34:127-168

Conley DJ, Schelske CL, Stoermer EF (1993) Modification of the biogeochemical cycle of silica with eutrophication. Mar Ecol Prog Ser 101:179-192

del Amo Y, Le Pape O, Tréguer P, Quéguiner B, Ménesguen A, Aminot A (1997) Impacts of high-nitrate freshwater inputs on macrotidal ecosystems. I. Seasonal evolution of nutrient limitation for the diatom dominated phytoplankton of the Bay of Brest (France). Mar Ecol Prog Ser 161:213-224

DeMott WR (1998) Utilization of a cyanobacterium and a phosphorus-defficient green alga as complementary resources by daphnids. Ecology 79:2463-2481

DeMott WR, Muller-Navarra DC (1997) The importance of highly unsaturated fatty acids in zooplankton nutrition: evidence from experiments with Daphnia, a cyanobacterium and lipid emulsions. Freshw Biol 38:649-664

Dortch Q, Whitledge TE (1992) Does nitrogen or silicon limit phytoplankton production in the Mississippi River plume and nearby regions? Cont Shelf Res 12:1293-1309

Edler L (1979) Recommendations on methods for marine biological studies on the Baltic Sea. Phytoplankton and chlorophyll. Publ Baltic Mar Biol 5:1-38

Egge JK, Aksnes DL (1992) Silicate as regulating nutrient in phytoplankton competition. Mar Ecol Prog Ser 83:281-289

Fisher TR, Harding LW Jr, Stanley DW, Ward LG (1988) Phytoplankton, nutrients and turbidity in the Chesapeake, Delaware and Hudson estuaries. Estuar Coast Shelf Sci 27:61-93

Fisher TR, Peel ER, Ammerman JW, Harding LW Jr (1992) Nutrient limitation of phytoplankton in Chesapeake Bay. Mar Ecol Prog Ser 82:51-63

Fulton RS III, Paerl HW (1987) Effects of colonial morphology on zooplankton utilization of algal resources during blue-green algal (Microcystis aeruginosa) blooms. Limnol Oceanogr 32:634-644

Granéli E, Carlsson P, Turner JF, Tester PA, Béchemin C, Dawson R, Funari E (1999) Effects of N:P:Si ratios and zooplankton grazing on phytoplankton communities in the northern Adriatic Sea. I. Nutrients, phytoplankton biomass, and polysaccharide production. Aquat Microb Ecol 18:37-54
Grover JP, Sterner RW, Robinson JL (1999) Algal growth in warm temperate reservoirs: nutrient-dependent kinetics of individual taxa and seasonal patterns of dominance. Arch Hydrobiol 145:1-23

Haas LW (1982) Improved epifluorescence microscopy for observing planktonic microorganisms. Ann Inst Océanogr 58(Suppl):261-266

Humborg C, Ittekkot V, Cociasu A, von Bodungen B (1997) Effect of the Danube River dam on Black Sea biogeochemistry and ecosystem structure. Nature 386:385-388

INTERREG-II (2000) Estudo dos 'blooms' de cianobactérias associados a variações de caudal no Rio Guadiana (Study of cyanobacteria blooms associated with discharge variations in the Guadiana River). Contract No. 16/REG II/6/96, Final report University of Algarve, Faro (in Portuguese)

Kilham P, Hecky RE (1988) Comparative ecology of marine and freshwater phytoplankton. Limnol Oceanogr 33(4, Part 2): 776-795

Kirkwood DS (1992) Stability of solutions of nutrients salts during storage. Mar Chem 38:151-164

Liss PS (1976) Conservative and non-conservative behaviour of dissolved constituents during estuarine mixing. In: Burton JD, Liss PS (eds) Estuarine chemistry. Academic Press, London, p 93-127

Lund JWG, Kipling C, Le Cren ED (1958) The inverted microscope method of estimating algal numbers and the statistical basis of estimations made by counting. Hydrobiologia 11:143-170

Milliman JD (1997) Blessed dams or damned dams? Nature 386:325-327

Morales JA (1997) Evolution and facies architecture of the mesotidal Guadiana River delta (S.W. Spain-Portugal). Mar Geol 138:127-148

Officer CB, Ryther JH (1980) The possible importance of silicon in marine eutrophication. Mar Ecol Prog Ser 3:83-91

Oliveira MRL (1985) Relatório dos estudos biológicos realizados no rio Guadiana e na estação de tratamento de águas da Vila de Mértola. Internal report No. 103, IPIMAR, National Institute for Fisheries and Marine Research, Lisbon (in Portuguese)

Oliveira MRL (1991) Eutrofização do Rio Guadiana - 'blooms' de Cyanophyceae e influência na ictiofauna; techn Sci Rep 42. IPIMAR, National Institute for Fisheries and Marine Research, Lisbon (in Portuguese)

Oremland RS, Capone DS (1988) Use of 'specific' inhibitors in biogeochemistry and microbial ecology. Adv Microb Ecol 10:286-383

Paasche E (1980) Silicon. In: Morris I (ed) The physiological ecology of phytoplankton. Blackwell, Oxford, p 258-284

Paerl HW (1988) Growth and reproductive strategies of freshwater blue-green algae (cyanobacteria). In: Sandgren CD (ed) Growth and reproductive strategies of freshwater phytoplankton. Cambridge University Press, Cambridge, p 261-315

Parsons TR, Maita Y, Lalli CM (1984) A manual of chemical and biological methods for seawater analysis. Pergamon Press, Oxford

Redfield AC, Ketchum BH, Richards FA (1963) The influence of organisms in the composition of seawater. In: Hill MN (ed) The sea, Vol II. Wiley, New York, p 26-77

Reynolds CS (1999) Non-determinism to probability, or N:P in the community ecology of phytoplankton. Arch Hydrobiol 146:23-35

Rocha O, Duncan A (1985) The relationship between cell carbon and cell volume in freshwater algal species used in zooplankton studies. J Plankton Res 7:279-294

Ryther JH, Officer CB (1981) Impact of nutrient enrichment on 
water uses. In: Neilson, BJ, Cronin LE (eds) Estuaries and nutrients. Humana Press, Clifton, NJ, p 247-261

Sakshaug E, Olsen Y (1986) Nutrient status of phytoplankton blooms in norwegian waters and algal strategies for nutrient competition. Can J Fish Aquat Sci 43:389-396

Schelske CL, Stoermer EF (1971) Eutrophication, silica depletion and predicted changes in algal quality in Lake Michigan. Science 173:423-424

Smayda TJ (1990) Novel and nuisance phytoplankton blooms in the sea: evidence of a global epidemic. In: Granéli E, Sundstrom B, Edler L, Anderson D (eds) Toxic marine phytoplankton. Elsevier, New York, p 29-40

Smith VH, Bennett SJ (1999) Nitrogen: phosphorus supply ratios and phytoplankton community structure in lakes. Arch Hydrobiol 146:37-53

Sommer U (1985) Comparison between steady-state and and non steadystate competition: experiments with natural phytoplankton. Limnol Oceanogr 30:335-346

Sommer U (1989) The role of Competition for Resources in Phytoplankton succession. In: Sommer U (ed) Plankton ecology-succession in plankton communities. Brock/ Springer Series in Contemporary Bioscience, SpringerVerlag, Berlin, p 57-106

Sommer U (1993) Phytoplankton competition in Plußsee: a field test of the resource ratio hypothesis. Limnol Oceanogr 38:838-845

Sommer U (1999) A comment on the proper use of nutrient ratios in microalgal ecology. Arch Hydrobiol 146:23-35

Sterner RW (1989) The role of grazers in phytoplankton succession. In: Sommer U (ed) Plankton ecology—succession in plankton communities. Brock/Springer Series in Contemporary Bioscience. Springer-Verlag, Berlin, p 107-170

Editorial responsibility: Otto Kinne (Editor),

Oldendorf/Luhe, Germany
Strathmann RR (1967) Estimating the organic carbon content of phytoplankton from cell volume or plasma volume. Limnol Oceanogr 12:411-418

Tilman D (1981) Test of resource competition theory using four species of Lake Michigan algae. Ecology 62:802-815

Tilman D, Kiesling RL (1984) Freshwater algal taxonomy: taxonomic tradeoffs in the temperature dependence of nutrient competitive abilities. In: Klug MJ, Reddy CA (eds) Current perspectives in microbial ecology. American Society of Microbiology, Washington, DC, p 314-319

Tilman D, Matston M, Langer S (1981) Competition and nutrient kinetics along a temperature gradient: an experimental test of mechanistic approach to niche theory. Limnol Oceanogr 26:1020-1033

Tilman D, Kilham SS, Kilham P (1982) Phytoplankton community ecology: the role of limiting nutrients. Annu Rev Ecol Syst 13:349-372

Turner RE, Rabalais NN (1994) Coastal eutrophication near the Mississippi river delta. Nature 368:619-621

Utermöhl H (1958) Zur Vervollkommnung der quantitativen Phytoplankton-Methodik. Mitt Int Ver Theor Angew Limnol 9:1-38

van Bennekom AJ, Salomons W (1981) In: Martin JM, Burton JD, Eisma D (eds) River inputs to ocean systems. UNEP, IOC, SCOR, United Nations, New York, p 33-51

Vasconcelos VM (1993) Toxicity of cyanobacteria in Lakes of North Central Portugal. Ecological implications. Verh Int Verein Limnol 25:694-697

Verity PG, Robertson CY, Tronzo CR, Andrews MG, Nelson JR, Sieracki ME (1992) Relationships between cell volume and the carbon and nitrogen content of marine photosynthetic nanoplankton. Limnol Oceanogr 37:1434-1446

Submitted: February 13, 2001, Accepted: May 31, 2001

Proofs received from author(s): February 12, 2002 